\title{
KEBIJAKAN PENGELOLAAN EKOSISTEM LAUT AKIBAT PERTAMBANGAN TIMAH DI PROVINSI BANGKA BELITUNG
}

\author{
Tanti Rismika ${ }^{1}$, Eko Priyo Purnomo ${ }^{2}$ \\ 1, 2 Department of Government Affairs and Administration, Jusuf Kalla School of \\ Government, Universitas Muhammadiyah Yogyakarta (UMY) \\ Email: ${ }^{1}$ tantirismika0@gmail.com, ${ }^{2}$ eko@umy.ac.id
}

Article Histori:

Submited: 29/11/2018

Review: 24/04/2019

Editing: 25/04/2019

Publish: 29/04/2019

\begin{abstract}
Bangka Regency is one of the regions that has the potential of natural resources with abundant tin mineral content. Initially tin mining was mostly carried out on the land, but with the development of the times and depletion of tin sources on the ground began to shift towards the sea. Environmental problems arising from marine mining are increasing, which is exacerbating damage to marine ecosystems, damaged coral reefs, and a decline in fishing production with this decreasing fishermen's income. This study aims to determine the policies of the Bangka Regency Government in the management of marine ecosystems and to know the impact of damage to marine ecosystems due to tin mining. This research uses descriptive qualitative approach method aims to describe the phenomena that occur at this time. The results of this study describe the contents of the marine mining policy as regulated No. 32 of 2009 concerning Environmental Protection and Management which aims to ensure the survival of living things and the preservation of ecosystems; Policy benefits; Management of Sea Water Pollution Control which includes: Environmental management objectives, Management Location, Time of Management and Implementers of Management and Management of B3 Waste; and Sea Water Quality Measurement Results.
\end{abstract}

Keyword: Mining Policy, Waste Management, Seawater Quality Measurement

\section{PENDAHULUAN}

Pertambangan timah merupakan Sumber Pendapatan Asli Daerah (PAD) terbesar bagi Kabupaten Bangka selama ini. Pulau Bangka merupakan salah satu wilayah yang memiliki petensi sumber daya alam dengan kandungan mineral timah yang melimpah. Demikian pula dengan wilayah Bangka memiliki peran sangat strategis sebagai salah satu kabupaten penghasil timah di pulau Bangka Belitung. Pendapatan Daerah Kabupaten Bangka tahun anggaran 2015 setelah perubahan dengan target Rp. 1 trilyun 164 milyar lebih dapat terealisasi Rp 1 trilyun 73 miliar lebih atau 92,53\%. Pendapatan daerah tersebut diantaranya berasal dari pendapatan asli daerah 
terealisasi Rp 129 milyar 295 juta lebih atau 94,52\% dari target Rp 136 milyar 797 juta lebih serta pendapatan lainnya berasal dari pos pajak daerah, restribusi daerahdan pendapatan lainnya. Pendapatan asli daerah yang sah berupa pendapatan hibah dari PT Timah, perusahaan smelter dan kapal isap senilai $\operatorname{Rp} 9$ miliar. (Bangka.go.id)

Timah merupakan ekspor terbesar yaitu berperan 83,37 persen dari total ekspor Provinsi Kepulauan Bangka Belitung. Tujuan utama ekspor timah Mei 2015 adalah Singapura yang mencapai US\$32,82 juta atau 49,04 persen dari keseluruhan ekspor timah, diikuti Belanda US $\$ 7,44$ juta (11,12 persen), India US $\$ 5,33$ juta $(7,96$ persen), Taiwan US\$5,11 juta $(7,64$ persen), dan Jepang US\$3,64 juta (5,44 persen). Timah tersebut banyak digunakan untuk solder, industri plating, untuk bahan dasar kimia, kuningan dan perunggu, industri gelas, dan berbagai macam aplikasi lain (BPS Kabupaten Bangka).

Pengoperasian pertambangan timah dilakukan di darat maupun di laut. Awalnya pertambangan timah marak dilakukan didarat, namun seiringnya perkembangan zaman dan menipisnya sumber timah didarat mulai bergeser menuju laut. Meskipun pertambangan memiliki izin namun pertambangan berdampak positif dan negatif. Dampak positif bagi pemerintah yaitu terciptanya lapangan kerja, mengurangi tingkat pengangguran dan menekan angka kemiskinan khususnya di daerah tersebut. Pendapatan pemerintah juga akan meningkat dengan diberlakukannya pajak terhadap pengelolaan sumber daya alam tersebut (Wahyuni, Sasongko, P. Sasongko. 2013).

\section{Tabel 1. Potensi Sumber Daya Mineral (Ton) Menurut Kabupaten tahun 2015}

\begin{tabular}{clr}
\hline Kab/Kota & \multicolumn{1}{c}{ Potensi } & $\begin{array}{c}\text { Kapasitas } \\
\text { Potensi }\end{array}$ \\
\hline Kab. & a. Timah & 350.000 .000 \\
Bangka & b. Bauksit & 180 \\
& c. Monasit & 439 \\
\hline Kab. & a. Timah & 92.793 \\
Belitung & b. Monasit & 3.404 \\
\hline Kab. & a. Timah & 1.042 .200 .000 \\
Bangka & b. Monasit & 471.088 .267 \\
Barat & c. Xenotim & 17.395 .231 \\
\hline Kab. & a. Titan Plaser & 6.732 .764 \\
Bangka & b. Timah & 127.105 \\
Tengah & c. Monasit & 138.735 .432 \\
\hline Kab. & a. Besi Primer & 58.765 \\
Bangka & b. Timah & 148.130 \\
Selatan & c. Monasit & 182 \\
\hline & a. Besi Primer & 35.856 .709 \\
Kab. & b. Seng & 12.230 .000 \\
Belitung & c. Timah & 16.583 .226 \\
Timur & d. Timbal & 12.230 .000 \\
& e. Monasit & 102.059 .872 \\
& f. Xenotim & 4.014 .539 \\
\hline
\end{tabular}

Sumber: Provinsi Bangka Belitung, 2016

Dari tabel 1 di atas menunjukan bahwa jumlah produksi bijih timah dan logam menurut Kecamatan di Kabupaten Bangka lebih banyak di Belinyu dengan bijih timah 2946,508 dan logam timah 3,080.75.

Sedangkan dampak negative yang akibat dari pertambangan timah dilaut yaitu rusaknya lingkungan alam, tercemarnya air laut, terjangkit penyakit bagi masyarakat di daerah pesisir, rusaknya ekosistem laut seperti terumbu 
karang dan penghuni laut lainnya, penurunan pendapatan nelayan berarti menurunkan produksi ikan setiap tahunnya dan terjadi konflik antar pengusaha tambang dan nelayan. Harian Kompas (25 April 2012) menyatakan bahwa masyarakat bangka yang terdiri dari pengusaha, pelaku pariwisata, nelayan, peneliti laut, dan pemerhati lingkungan mendesak pemerintah daerah agar segera membatasi daerah penambangan timah lepas pantai yang saat ini marak di sekitar Pulau Bangka. Kerusakan lingkungan laut sejak adanya aktivitas penambangan telah merugikan sektor perikanan dan wisata di Pulau Bangka. konflik antara nelayan dan petambang timah rakyat lepas pantai kerap muncul. Bangka Pos (28 Desember 2015) Memberitakan bahwa Saat ini ada 70 lebih jumlah kapal isap yang beroperasi di perairan Bangka. Laut menjadi padat oleh aktivitas kapal isap. Produktivitas nelayan jadi terganggu dan terancam kehilangan mata pencaharian. Ada 16.000 nelayan harian dari 45 ribu nelayan mengalami akibat langsung. Hasil tangkap ikan mulai menurun dan semakin jauh diatas 5 mil mendapatkan ikan lebih banyak dan terumbu karang terancam rusak akibat salah dalam pengelolaan sumber daya alamnya.

Tabel 2. Luas dan Kondisi Terumbu Karang di Kepulauan Bangka Tahun 2016

\begin{tabular}{|c|c|c|c|c|c|c|}
\hline \multirow[b]{2}{*}{ No } & \multirow[b]{2}{*}{ Kota } & \multirow{2}{*}{$\begin{array}{c}\text { Luas } \\
\text { Tutupan } \\
\text { (ha) }\end{array}$} & \multicolumn{4}{|c|}{ Persentase Luas Terumbu Karang (\%) } \\
\hline & & & $\begin{array}{c}\text { Sangat } \\
\text { Baik }\end{array}$ & Baik & Sedang & Buruk \\
\hline 1 & Pangkal Pinang & 0 & 0 & 0 & 0 & 0 \\
\hline 2 & Bangka & $9.162,4$ & 0 & 14,68 & 28,23 & 57,09 \\
\hline 3 & Bangka Tengah & $3.376,8$ & 0 & 0 & 100 & 0 \\
\hline 4 & Bangka Barat & 703,2 & 0 & 100 & 0 & 0 \\
\hline 5 & Bangka Selatan & 29.82 & 0 & 10 & 30 & 60 \\
\hline 6 & Belitung & $25.607,2$ & 0 & 100 & 0 & 0 \\
\hline 7 & Belitung Timur & $9.452,2$ & 0 & 60 & 40 & 0 \\
\hline & & $78.124,9$ & 0 & 46,48 & 23,93 & 29,60 \\
\hline
\end{tabular}

Sumber: Laporan Status Lingkungan Hidup Daerah Provinsi Bangka Belitun, 2016

Tabel 2. Di atas menjelaskan luasan dan kondisi terumbu karang di masingmasing kabupaten/kota yang ada di Kepulauan Bangka Belitung tahun 2016. Terlihat bahwa Kondisi terumbu karang di Kabupaten Belitung, seluruhnya dalam kondisi baik, seperti halnya kondisi terumbu karang di Kabupaten Bangka Barat. Kondisi sedang pada terumbu karang terdapat di Kabupaten Bangka, Bangka Tengah, Bangka Selatan, dan
Belitung Timur, sedangkan terumbu karang dengan kondisi rusak terdapat di Kabupaten Bangka 57,06\% dan Bangka Selatan 29,60\%. Khususnya dikabupaten Bangka terumbu karang 50 persen rusak akibat aktivitas penambangan timah dilaut karena pori-pori terumbu karang tertutup limbah penambangan yaitu lumpur sehingga membuat terumbu karang rusak. 
Grafik 1. Produksi Penangkapan Ikan (Ton) Kabupaten Bangka Tahun 2013-2016

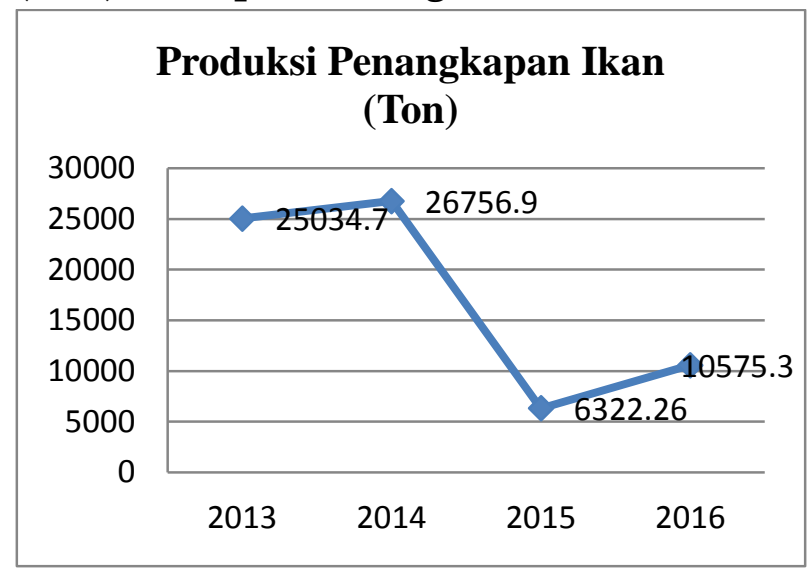

Sumber: BPS Provinsi Bangka Belitung, 2017

Produksi penangkapan ikan di Kabupaten Bangka pada tahun 2013 dan 2014 hasil tangkapan ikan sangat baik, kemudian pada tahun 2015 dan 2016 mengalami penurunan pendapatan hasil tangkapan ikan tahun 2015 menurun 6322.26 ton pada tahun 2016 naik 4253.04 ton jadi 10575.3 ton. Penurunan produksi penangkapan ikan lantaran adanya aktifitas penambangan timah di kawasan laut dengan ini menurunnya pendapatan nelayan karena terumbu karang rusak akibat tertutup lumpur dihasilkan dari limbah penambangan pasir timah di laut jadi hasil tangkapan ikan berkurang.

Kebijakan yang dikeluarkan oleh pemerintah daerah yang mengatur pengelolaan pertambangan timah yang ditujukan untuk mengurangi dampak kerusakan lingkungan serta memberikan kepastian hukum bagi pihak yang berkepentingan seperti pengusaha, masyarakat, perusahaan, dan pemda. Akan tetapi saat ini belum adanya pemantauan dan perhatian yang pasti dari pemerintah dalam pengelolaan ekosistem laut akibat pertambangan timah. Hal tersebut dikarenakan pemerintah melakukan pengelolaan sumber daya alam yang terjadi akibat buruk model pengelolaan sumber daya alam yang dicanangkan oleh Pemerintah. Karena dibuktikan pemerintah terlalu mudah mengeluarkan Izin Usaha Pertambangan (IUP) pertambangan meskipun secara lingkungan dan sosial ekonomi sesungguhnya tidak layak. Dalam permasalahan ini diperlukannya kebijakan yang tegas pada pengelolaan ekosistem laut untuk mengambil tindakan dan langkah yang cepat untuk menghentikan kegiatan penambangan timah baik yang mendapat izin (legal) atau yang tidak mendapatkan izin (ilegal). Karena Jika terus dibiarkan, maka kerusakan ekosistem laut bertambah parah dan masyarakat pesisir yang akan merasakan dampaknya.

\section{METODE}

Dalam Penelitian ini mengunakan metode pendekatan kualitatif deskriptif bertujuan untuk menggambarkan fenomena-fenomena yang terjadi saat ini. Selain itu juga mendeskripsikan suatu kondisi secara sistematis, faktual, dan akurat mengenai fakta dengan mengumpulkan informasi aktual secara rinci yang menggambarkan gejala yang ada, mengindetifikasi masalah atau memeriksa kondisi. Kemudian melakukan analisis data dengan memperbanyak informasi, mencari hubungannya, membandingkan, dan menemukan hasil bukan berbentuk angka-angka tetap berupa gambaran dan kata-kata. Penelitian ini akan mengungkapkan masalah-masalah 
kerusakan-kerusakan ekosistem laut dan kebijakan pemeritah kabupaten Bangka dalam Pengelolaan ekosistem laut akibat pertambangan timah.

\section{TELAAH TEORITIS}

\section{Kebijakan Publik}

Wahab (Hosio, 2007) mengemukakan bahwa istilah kebijakan sendiri masih terjadi silang pendapat dan merupakan ajang perdebatan para ahli. Maka untuk memahami istilah kebijakan ada beberapa pedoman yaitu : Kebijakan harus dibedakan dari keputusan

a. Kebijakan sebenarnya tidak serta merta dapat dibedakan dari administrasi

b. Kebijakan mencakup perilaku dan harapan-harapan

c. Kebijakan mencakup ketiadaan tindakan ataupun adanya tindakan

d. Kebijakan biasanya mempunyai hasil akhir yang akan dicapai

e. Setiap kebijakan memiliki tujuan atau sasaran tertentu baik eksplisit maupun implisit

f. Kebijakan muncul dari suatu proses yang berlangsung sepanjang waktu

g. Kebijakan meliputi hubunganhubungan yang bersifat antar organisasi dan yang bersifat intra organisasi

h. Kebijakan publik meski tidak ekslusif menyangkut peran kunci lembagalembaga pemerintah

i. Kebijakan itu dirumuskan atau didefinisikan secara subyektif

Sedangkan Rusli (2013) mengatakan, kebijakan publik merupakan modal utama yang dimiliki pemerintah untuk menata kehidupan masyarakat dalam berbagai aspek kehidupan. Dikatakan sebagai modal utama karena hanya melalui kebijakan publiklah pemerintah memiliki kekuatan dan kewenangan hukum untuk memanejemen masyarakat dan sekaligus memaksakan segala ketentuan yang telah ditetapkan. Walaupun memaksa, akan tetapi sah dan legitimate karena didasari regulasi yang jelas. Kebijakan publik adalah alat untuk mencapai tujuan public bukan tujuan orang perorang atau golongan dan kelompok. Meskipun sebagai alat (tool) keberadaan kebijakan publik sangat penting dan sekaligus krusial. Penting karena keberadaannya sangat menentukan tercapainya sebuah tujuan, meskipun masih ada sejumlah prasyarat atau tahapan lain yang harus dipenuhi sebelum sampai pada tujuan yang dikehendaki.

Easton sebagaimana dikutip Leo Agustino (2009: 19) memberikan definisi kebijakan publik sebagai " the autorative allocation of values for the whole society". Definisi ini menegaskan bahwa hanya pemilik otoritas dalam sistem politik (pemerintah) yang secara syah dapat berbuat sesuatu pada masyarakatnya dan pilihan pemerintah untuk melakukan sesuatu atau tidak melakukan sesuatu diwujudkan dalam bentuk pengalokasian nilai-nilai. Hal ini disebabkan karena pemerintah termasuk ke dalam "authorities in a political system" yaitu para penguasa dalam sistem politik yang terlibat dalam urusan sistem politik sehari-hari dan mempunyai tanggungjawab dalam suatu masalah tertentu dimana pada suatu titik mereka diminta untuk mengambil keputusan di kemudian hari kelak diterima 
serta mengikat sebagian besar anggota masyarakat selama waktu tertentu.

Beberapa pendapat ahli yang mendefinisikan kebijakan publik adalah suatu tindakan yang dilakukan pemerintah dalam merespon suatu masalah publik. Dye menyatakan bahwa kebijakan public adalah apapun yang dipilih oleh pemerintah untuk dilakukan atau tidak dilakukan. Sedangkan Rose mengatakan bahwa kebijakan adalah serangkaian kegiatan yang sedikit banyak berhubungan beserta konsekuensi-konsekuensi bagi mereka yang bersangkutan daripada sebagai keputusan yang berdiri sendiri. Sedangkan pengertian dan pemahaman akan kebijakan public yang dikemukan oleh Friedrich menegaskan kebijakan public sebagai suatu arah tindakan yang diusulkan oleh seseorang, kelompok atau pemerintah dalam suatu lingkungan tertentu yang memberikan hambatanhambatan dan peluang-peluang terhadap kebijakan yang diusulkan untuk menggunakan dan mengatasi dalam rangka mencapai tujuan atau merealisasikan suatu sasaran atau suatu maksud tertentu (Winarno,2013).

Nugroho (2004) berpendapat bahwa kebijakan Publik adalah jalan mencapai tujuan bersama yang dicita-citakan. Kebijakan publik yang terbaik adalah kebijakan yang mendorong setiap warga masyarakat untuk membangun daya saingnya masing-masing, dan bukan semakin menjerumuskan ke dalam pola ketergantungan dapat disimpulkan kebijakan public adalah suatu tindakan atau keputusan yang dilakukan pemerintah untuk memecahkan sebuah masalah yang terjadi. Bertujuan untuk mendorong masayarakat untuk membangun daya saing dan mencapai tujuan atau merealisasikan suatu sasaran.

\section{Implementasi Kebijakan}

Implementasi adalah suatu tindakan atau pelaksanaan dari sebuah rencana yang sudah disusun secara matang dan terperinci (Nurdin, 2013). Meter dan Horn (dalam Winarno, 2008:146) membatasi implementasi kebijakan sebagai tindakan tindakan yang dilakukan oleh individuindividu (atau kelompok-kelompok) pemerintah maupun swasta yang diarahkan untuk mencapai tujuan-tujuan yang telah ditetapkan dalam keputusankeputusan kebijakan sebelumnya. Lester dan Stewart yang dikutip oleh Winarno, menjelaskan bahwa implementasi kebijakan adalah: "Implementasi kebijakan dipandang dalam pengertian luas merupakan alat administrasi hukum dimana berbagai aktor, organisasi, prosedur dan teknik yang bekerja bersamasama untuk menjalankan kebijakan guna meraih dampak atau tujuan yang diinginkan”. (Winarno, 2013).

Grindle 1980 (Dalam Mutiarin 2014) menyatakan bahwa proses umum implementasi dapat dimulai ketika tujuan dan sasaran telah dispesifikasikan, program-program telah didesain, dan dana telah dialokasikan untuk pencapaian tujuan. Ketiga hal tersebut merupakan syarat-syarat dasar (the Content of policy) dan konteks kebijakan (the context od policy) yang terkait dengan formulasi kebijakan. 
Keberhasilan implementasi menurut Grindle dipengaruhi oleh 2 variabel besar, yakni isi kebijakan (content of policy) dan lingkungan implementasi (context of implementation).

Variabel isi kebijakan ini mencakup: (1) sejauh mana dalam isi kebijakan; (2) jenis manfaat yang diterima oleh target group, sebagai contoh, masyarakat di wilayah slum areas lebih suka menerima program air bersih atau pelistrikan daripada menerima program kredit sepeda motor; (3) sejauh mana perubahan yang diinginkan dari sebuah dari sebuah kebijakan. Suatu program yang berujuan mengubah sikap dan prilaku kelompok sasaran relative lebih sulit diimplementasikan daripada program yang sekedar memberikan bantuan kredit dan bantuan beras kepada kelompok miskin; (4) apakah letak sebuah program udah tepat. Misalnya, ketika BKKBN memiliki program peningkatan kesejahteraan keluarga dengan memberikan bantuan dana kepada keluarga prasejahtera, banyak orang menanyakan apakah letak program ini sudah tepat berada di BKKBN; (5) apakah sebuah kebijakan telah menyebutkan implementornya dengan rinci; dan (6) apakah sebuah program didukung oleh sumber daya yang memadai. Sedangkan variabel lingkungan kebijakan mencakup: (1) seberapa besar kekuasaan, kepentingan, dan strategi yang dimiliki oleh para aktor yang terlibat dalam implementasi kebijakan; (2) karakteristik institusi dan rejim yang sedang berkuasa; (3) tingkat kepatuhan dan responsivitas kelompok sasaran.

\section{Pengelolaan Ekosistem}

Pengelolaan berasal dari kata manajemen atau administrasi. Hal tersebut seperti yang dikemukakan oleh Usman bahwa management diterjemahkan dalam bahasa Indonesia menjadi manajemen atau pengelolaan. Dalam beberapa konteks keduanya mempunyai persamaan arti, dengan kandungan makna to control yang artinya mengatur dan mengurus (Hardyanti, 2012). Sedangkan dalam kamus Bahasa indonesia menyebutkan bahwa pengelolaan adalah proses atau cara perbuatan mengelola atau proses melakukan kegiatan tertentu dengan menggerakkan tenaga orang lain, proses yang membantu merumuskan kebijaksanaan dan tujuan organisasi atau proses yang memberikan pengawasan pada semua hal yang terlibat dalam pelaksanaan kebijaksanaan dan pencapai tujuan (Daryanto, 1997).

Fattah, (2011) berpendapat bahwa dalam proses manajemen terlibat fungsifungsi pokok yang ditampilkan oleh seorang manajer atau pimpinan, yaitu perencanaan (planning), pengorganisasian (organising), pemimpin (leading), dan pengawasan (controlling). Oleh karena itu, manajemen diartikan sebagai proses merencanakan, mengorganising, memimpin, dan mengendalikan upaya organisasi dengan segala aspeknya agar tujuan organisasi tercapai secara efektif dan efisien. Sedangkan Follet mendefinisikan pengelolaan adalah seni atau proses dalam menyelesaikan sesuatu yang terkait dengan pecapaian tujuan. Dalam penyelesaian akan sesuatu tersebut, terdapat tiga faktor yang 
terlibat yaitu Pertama, adanya penggunaan sumber daya organisasi, baik sumber daya manusia maupun faktor-faktor produksi lainya. Kedua, proses yang bertahap mulai dari perencanaan, pengorganisasian, pengarahan dan pengimplementasian, hingga pengendalian dan pengawasan. Ketiga, Adanya seni dalam penyelesaian pekerjaan (Sule dan Saefullah. 2009).

Beberapa pendapat ahli yang menyatakan bahwa manajemen adalah suatu proses yang terdiri dari rangkaian kegiatan, seperti perencanaan, pengorganisasian, penggerakan dan pengendalian/pengawasan, yang dilakukan untuk menentukan dan mencapai tujuan yang telah ditetapkan melalui pemanfaatan sumberdaya manusia dan sumberdaya lainnya. Koontz dan O'donnel menyatakan bahwa manajemen adalah usaha untuk mencapai suatu tujuan tertentu melalui kegiatan orang lain. Sedangkan Terry mengatakan bahwa manajemen merupakan suatu proses khas yang terdiri dari tindakan-tindakan perencanaan, pengorganisasian, penggerakan dan pengendalian yang dilakukan untuk menentukan serta mencapai sasaran yang telah ditentukan melalui pemanfaatan sumberdaya manusia dan sumberdaya lainnya. Pengertian dan pemahaman akan manajemen oleh Stoner menegaskan manajemen adalah proses perencanaan, pengorganisasian dan penggunakan sumberdaya organisasi lainnya agar mencapai tujuan organisasi yang telah ditetapkan. Sedangkan Lee berpendapat bahwa manajemen adalah seni dan ilmu perencanaan pengorganisasian, penyusunan, pengarahan dan pengawasan daripada sumberdaya manusia untuk mencapai tujuan yang telah ditetapkan (Heriyanto, 2009).

Manajemen dapat diartikan sebagai kegiatan apa saja yang akan dilakukan oleh seorang manajer dalam kegiatan manajerialnya. Sehingga kegiatan manajerial yang dilakukan oleh manajer tersebut dapat dikatakan sebagai kegiatan proses manajemen. Proses tersebut bermula dari pembuatan perencanaan sampai pada pengadaan pengawasan terhadap pelaksanaan rencana tersebut. Pengawasan yang dilakukan bertujuan untuk mengetahui efektif atau tidaknya pelaksanaan rencana sehingga tujuan yang telah ditetapkan dapat tercapai (Arif dan Zulkarnain, 2008).

Sedangkan Ekosistem adalah satu kelompok yang mempunyai ciri khas tersendiri yang terdiri dari beberapa komunitas yang berbeda. pengertian ekosistem terdapat dalam pasal 1 ayat $5 \mathrm{UU}$ No. 32 tahun 2009, yaitu ekosistem adalah tatanan unsur lingkungan hidup yang merupakan kesatuan utuh-menyeluruh dan saling mempengaruhi dalam membentuk keseimbangan, stabilitas, dan produktivitas lingkungan hidup. Dari pengertian tersebut, jelaslah bahwa syarat terbentuknya ekosistem ialah adanya keteraturan hubungan dan ketergantungan antar sub-ekosistem. Di dalam ekosistem, organisme yang ada selalu berinteraksi secara timbal balik dengan lingkungannya. Interaksi timbal balik ini membentuk suatu sistem yang kemudian kita kenal sebagai sistem ekologi atau ekosistem. Dengan kata 
lain Ekosistem merupakan suatu satuan fungsional dasar yang menyangkut proses interaksi organisme hidup dengan lingkungannya. Lingkungan yang dimaksud dapat berupa lingkungan biotik (makhluk hidup) maupun abiotik (non makhluk hidup). Sebagai suatu sistem, di dalam suatu ekosistem selalu dijumpai proses interaksi antara makhluk hidup dengan lingkungannya, antara lain dapat berupa adanya aliran energi, rantai makanan, siklus biogeokimiawi, perkembangan, dan pengendalian. Ekosistem diartikan sebagai tatanan kesatuan secara utuh menyeluruh antara segenap komponen lingkungan hidup yang saling berinteraksi membentuk suatu kesatuan yang teratur. Keteraturan tersebut ada dalam suatu keseimbangan tertentu yang bersifat dinamis. Artinya, bisa terjadi perubahan, baik besar maupun kecil, yang disebabkan oleh faktor alamiah maupun akibat ulah manusia (Utomo, 2014).

\section{HASIL DAN PEMBAHASAN}

\section{Kebijakan Pertambangan dan Lingkungan Hidup}

Mempertimbangkan perkembangan nasional maupun internasional, UndangUndang Nomor 11 Tahun 1967 tentang Ketentuan-Ketentuan Pokok Pertambangan sudah tidak sesuai lagi sehingga dibutuhkan perubahan peraturan perundang-undangan di bidang pertambangan mineral dan batubara yang dapat mengelola dan mengusahakan potensi mineral dan batubara secara mandiri, andal, transparan, berdaya saing, efisien, dan benwawasan lingkungan, guna menjamin pernbangunan nasional secara berkelanjutan. Dengan ini disahkannya Undang-Undang Nomor 4 Tahun 2009 tentang Pertambangan Mineral dan Batubara (UU Minerba), menggantikan Undang-Undang Nomor 11 Tahun 1967 tentang Ketentuan-ketentuan Pokok Pertambangan. Perubahan mendasar yang terjadi adalah perubahan dari sistem kontrak karya dan perjanjian menjadi sistem perijinan, sehingga Pemerintah tidak lagi berada dalam posisi yang sejajar dengan pelaku usaha dan menjadi pihak yang memberi ijin kepada pelaku usaha di industri pertambangan mineral dan batubara. Falsafah diterbitkannya UU No. 4 Tahun 2009 adalah adanya perubahan paradigma terhadap pengelolaan sumber daya alam.

Prosedur pengurusan izin usaha pertambangan dengan mengajukan permohonan izin kemudian melengkapi persyaratan adminitrasi terlebih dahulu yang telah ditetapkan. Kemudian IUP eksplorasi diberikan berdasarkan permohonan dari badan usaha, koperasi, dan perseorangan yang telah mendapatkan Wilayah Izin Usaha Pertambangan (WIUP). Dalah hal Izin Usaha Pertambangan Eksplorasi harus meliputi kegiatan Penyelidikan umum, Eksplorasi, dan Study kelayakan Dalam hal kegiatan eksplorasi dan kegiatan studi kelayakan, pemegang IUP eksplorasi yang mendapatkan mineral atau batubara yang tergali wajib melaporkan kepada pemberi IUP.

Kemudian setelah proses pemberi Izin Usaha Pertambangan setiap usaha pertambangan perlunya izin lingkungan sebagaimana diatur Nomor 32 Tahun 2009 Tentang Perlindungan dan Pengelolaan 
Lingkungan Hidup yang bertujuan untuk menjamin kelangsungan kehidupan makhluk hidup dan kelestarian ekosistem, melestarikan fungsi lingkungan hidup, menjamin terpenuhinya keadilan generasi masa kini dan generasi masa depan, mengendalikan pemanfaatan sumber daya alam secara bijaksana, mewujudkan pembangunan berkelanjutan dan mencegah terjadinya pencemaran dan/atau kerusakan lingkungan hidup yang meliputi perencanaan, pemanfaatan, pengendalian, pemeliharaan, pengawasan, dan penegakan hukum.

Kebijakan pemerintah dalam pengelolaan ekosistem laut akibat pertambangan ini berjalan efektif dan efisien harus sesuai dengan prosedur/mekanisme yang ditetap pemerintah. Maka kebijakan pemerintah dalam pengelolaan laut pada kegiatan pertambangan laut sebagaimana yang diatur UU No. 32 Tahun 2009 Pasal 36 ayat 1 yang mengatakan bahwa Setiap usaha dan/atau kegiatan pertambangan wajib memiliki izin lingkungan. Permohonan Izin Lingkungan dilengkapi dengan dokumen AMDAL (KA, draft Andal dan RKL-RPL), dokumen pendirian Usaha dan/atau Kegiatan; dan profil Usaha dan/atau Kegiatan.

Dari penjelasan diatas, terlihat bahwa semakin meningkatnya kegiatan penambangan mengandung tingkat resiko pencemaran dan perusakan lingkungan hidup sehingga struktur dan fungsi dasar ekosistem yang menjadi penunjang kehidupan dapat rusak. Pencemaran dan perusakan lingkungan hidup itu akan merupakan beban sosial, yang akhirnya masyarakat dan pemerintah harus menanggung biaya pemulihannya. Terpeliharanya keberlanjutan fungsi lingkungan hidup merupakan kepentingan rakyat sehingga menuntut tanggung jawab, keterbukaan, dan peran anggota masyarakat, yang lembaga swadaya masyarakat, kelompok masyarakat adat, dan lain-lain, untuk memelihara dan meningkatkan daya dukung dan daya tamping lingkungan hidup yang menjadi tumpuan keberlanjutan pembangunan. Pembangunan yang memadukan lingkungan hidup, termasuk sumber daya alam, menjadi sarana untuk mencapai keberlanjutan pembangunan dan menjadi jaminan bagi kesejahteraan dan mutu hidup generasi masa kini dan generasi masa depan. Dalam rangka pemulihan ekosistim laut yang sudah rusak melalui upaya reklamasi yang memerlukan dana yang sangat besar. Kebijakan pertambangan dan pengelolaan lingkungan sangat perlu disosialisasikan kepada masyarakat dan juga pada para calon investor agar dapat mengetahui aturanaturan yang ada dan ditetapkan pemerintah.

Pengelolaan Pengendalian Pencemaran Air Laut

Pengendalian pencemaran laut di KK/KI/KIP/BWD dilakukan melekat dengan proses operasi penambangan laut yang berlangsung di masing-masing jenis kapal penambangan. Kegiatan pengendalian pencemaran laut ini meliputi pengelolaan limbah hidrokarbon yang 
dihasilkan oleh operasional kapal adalah ceceran minyak, oli bekas, dan lain-lain, limbah cair seperti oli/pelumas bekas dan ceceran BBM (solar) serta lainnya yang dihasilkan akan ditangani PT Timah (Persero) Tbk., berdasarkan standard operasional procedure (SOP) mengacu pada peraturan menteri lingkungan hidup nomor 101 tahun 2014 tentang pengelolaan limbah B3. Dampak penurunan kualitas air laut menjadi penting mengingat penggunaan perairan laut oleh nelayan sebagai sumber mata pencahariannya. Selain itu perairan laut juga terkait erat dengan kawasan habitat terumbu karang, rumput laut dan biota perairan lainnya serta terkait dengan kegiatan wisata pantai. Kegiatan pertambangan di Kabupaten Bangka tidak mungkin bisa lepas dari peningkatan padatan tersuspensi dalam perairan laut. Tujuan pengelolaan lingkungan hidup:

1. Mencegah dan mengendalikan pencemaran laut yang bersumber dari limbah dari operasi KK/KI/KIP/BWD.

2. Mencegah dan menggendalikan pencemaran laut yang bersumber dari pemindahan dan pengangkutan limbah dari KK/KI/KIP/BWD ke TPS penimbunan limbah dilaut.

3. Menghindari kemungkinan konflik dengan masyarakat khususnya nelayan yang melakukan penangkapan ikan di laut, juga golongan masyarakat tertentu yang memanfaatkan laut sebagai obyek wisata bahari

Pengendalian pencemaran laut dilakukan di:

1. Pengendalian jumlah KK/KI/KIP/BWD dan Mitra yang beroperasi di laut dilakukan disetiap lokasi penambangan laut yang dekat dengan atau berpengaruh terhadaip ekosistem terumbu karang, vegetasi mangrove, habitat khusus, dan obyek wisata bahari.

2. Pengendalian pencemaran laut dilakukan di:

1) Setiap unit $\mathrm{KK} / \mathrm{KI} / \mathrm{KIP} / \mathrm{BWD}$ dan Mitra yang beroperasi di laut

2) Setiap kapal angkutan laut atau kapal penjangkaran yang memindahkan dan mengangkut liimbah hidrokarbon dan limbah padat/limbah domestik dari KK/KI/KIP/BWD ke pelabuhan darat.

Waktu Pengelolaan Dilakukan disaat KK/KI/KIP/BWD beroperasi di laut yaitu dengan pengendalian jumlah dan lokasi KK/KI/KIP/BWD dan mitra dilakukan selama kapal penambangan tersebut beroperasi di KP laut tertentu dimana sebagaian diantaranya merupakan daerah asuh, terumbu karang, habitat khusus, dan obyek wisata bahari. Dan Pelaksana Pengelolaan : Kuasa KK/KI/KIP/BWD (milik PT Timah dan Mitra) dan Kepala Lingkungan Hidup, Operasi Kapal Keruk Wilayah bersangkutan, PT Timah.

\section{Pengelolaan Limbah B3}

Peraturan Pemerintah Nomor 85 Tahun 1999 Tentang perubahan atas Peraturan Pemerintah No 18 Tahun 1999 tentang pengelolaan Limbah Bahan Beracun dan Berbahaya (Limbah B3) adalah sisa suatu usaha dan/atau kegiatan yang mengandung bahan berbahaya dan/atau beracun yang karena sifat dan/atau 
konsentrasinya dan/atau jimlah, baik secara langsung maupun tidak langsung, dapat memancarkan dan/atau merusakan lingkungan hidup, dan/atau dapat membahayakan lingkungan hidup, kesehatan, kelangsungan hidup manusia serta makhluk hidup lain. Pengelolaan limbah B3 yang bertujuan untuk mengindetifikasi Limbah B3, pelaku pengelolaan, kegiatan pengelolaan, tata laksana, dan sanksi.

Pengelolaan limbah B3 adalah kegiatan yang meliputi pengurangan, penyimpanan, pengumpulan, pengangkutan, pemanfaatan, pengolahan dan/atau penimbunan. Pengelolaan limbah B3 tidak dilakukan oleh sebab limbah tersebut diambil oleh pihak ketiga untuk dimanfaatkan kembali sesuai dengan macam dan karakteristiknya. Pada Tambang Perusahaan pengelolaan Limbah Bahan Berbahaya dan Beracun (LB3) Unit Penambangan Laut Bangka terhadap majun bekas oli, filter bekas oli, oli bekas, oil sludge yang berasal dari oil trap, accu bekas ditampung di tempat Penampungan Sementara Limbah Bahan Berbahaya dan Beracun (LB3) disetiap lokasi kapal produksi yang ada.

TPS Limbah Bahaya Berbahaya dan Beracun (LB3) Unit Produksi Laut Bangka memiliki izin penyimpanan sementara dari BLH Provinsi Kepulauan Bangka Belitung. Unit Produksi Laut Bangka bekerjsama dengan pihak III untuk melakukan penanganan, pengelolaan dan pengangkutan Limbah B3 yang telah dimiliki izin operasi dari Kementerian
Lingkungan Hidup dalam hal ini adalah PT. Valten Cahaya Anugrah untuk pengangkutan limbah B3 yang bekerjasama dengan PT. Tenang jaya dan PT. Muchtomas., Perusahaan tersebut secara rutin mengambil limbah Bahan Berbahaya dan Beracun (LB3) Unit Produksi Laut Bangka untuk diolah atau dimusnahkan dan didaur ulang kembali. Kewajiban pemegang izin penyimpanan limbah B3

1. Melakukan identifikasi Limbah B3 yang dihasilkan;

2. Pencatatan nama dan jumlah Limbah B3 yang dihasilkan;

3. Melakukan Penyimpanan Limbah B3;

4. Melakukan Pemanfaatan dan/atau Pengolahan dan/atau Penimbunan dan/atau menyerahkan kepada Pengumpul dan/atau Pengolah dan/atau Pemanfaat dan/atau Penimbun Limbah B3 yang memiliki izin.

5. Menyusun dan menyampaikan laporan Penyimpanan Limbah B3.

Prosedur tindakan sistem pengelolaan limbah Bahan Berbahaya dan Beracun (B3):

1. Melengkapi tempat penyimpanan sementara limbah B3 dengan kemiringan $1 \%$ ke satu arah, pembuatan saluran, bak penampung tumpahan minyak dan pemasangan papan nama.

2. Melengkapi kemasan limbah B3 dengan simbol dan label sesuai dengan peraturan yang berlaku.

3. Pelaporan inventarisasi limbah B3 setiap tiga bulan. 
Tabel 3. Daftar Pengelolaan Limbah B3 UPLB

\begin{tabular}{lllllll}
\hline \multirow{2}{*}{ No } & \multirow{2}{*}{ Bulan } & Jenis Limbah & \multicolumn{4}{c}{ Data Limbah (Kg) } \\
\cline { 3 - 6 } & & $\begin{array}{c}\text { Stok } \\
\text { Awal }\end{array}$ & Masuk & Keluar & $\begin{array}{c}\text { Stok } \\
\text { Akhir }\end{array}$ \\
\hline 1 & Oktober 2016 & Oli Bekas & 27.289 & 0 & 27.289 & 0 \\
& Solar Bekas & 2.929 & 0 & 2.929 & 0 \\
& & Filter Bekas & 0.954 & 0 & 0.954 & 0 \\
& & Grease & 0.616 & 0 & 0.616 & 0 \\
2 & \multirow{2}{*}{ Nopember 2016 } & Oli Bekas & 0 & 7.854 & - & 7.854 \\
& & Solar Bekas & 0 & 488 & - & 488 \\
& Filter Bekas & 0 & 1050 & - & 1050 \\
& & Grease Bekas & 0 & 0 & - & 0 \\
3 & Desember 2016 & Oli Bekas & & 3.179 & - & 11.033 \\
& & Solar Bekas & & 110 & - & 0.545 \\
& & Filter Bekas & & 525 & - & 1.575 \\
& Grease Bekas & & 0 & - & 0.215 \\
\hline
\end{tabular}

Sumber: PT Timah, 2016

Pengelolaan limbah B3 dan interaksi antar pelaku pengelolaan:

1. Penghasil

- Wajib melakukan reduksi, mengolah, dan/atau menimbun LB3. Jika tidak bisa, dapat diserahkan ke pihak ke-3 yang berizin.

- Menyimpan limbah B3 maksimal 90 hari, dapat diperpanjang jika limbah B3 yang dihasilkan kurang dari 50 $\mathrm{kg} /$ hari. Tempat penyimpanan mengikuti ketentuan teknis (KepKa Bapedal 01/1995).

- Memberikan simbol dan label di setiap kemasan dan symbol di tempat penyimpanan (Kepka Bapedal 05/1995).

- Memiliki sistem tangkap darurat.
- Membuat dan menyimpan catatan tentang jenis, karakteristik, jumlah, dan waktu limbah B3 dihasilkan dan diserahkan ke pihak ke-3, serta nama pengangkut yang melaksanakan pengiriman.

- Pelaporan minimal 6 bulan sekali kepala KLH, atau berdasarkan surat izin penyimpanan.

2. Pengumpul

- Pengumpul harus berbentuk badan usha dan membuat AMDAL untuk pengumpulan lebih dari 1 jenis LB3.

- Menyimpan limbah B3 maksimal 90 hari sebelum diserahan ke pihak lain.

- Memiliki sistem tanggap darurat.

- Memiliki laboratorium analisa LB3 dan tenaga terdidik di bidang pengelolaan LB3 
- Memiliki asuransi pencemaran lingkungan dengan nilai minimal Rp. 5 milyar.

- Membuat dan menyimpan catatan tentang jenis, karakteristik, jumlah, dan waktu limbah B3 diterima dan diserahkan ke pihak ke-3, serta nama pengangkut yang melaksana pengiriman.

- Melaporkan pencatatan minimal 6 bulan sekali kepada KLH, atau berdasarkan surat izin pengumpulan.

3. Pengangkut

- Pengangkut harus berbentuk badan usaha

- Dapat dilakukan oleh penghasil dengan ketentuan yang berlaku sama dengan pengangkut limbah B3.

- Memiliki rekomendasi dari KLH dan izin dari Departemen Perhubungan.

- Wajib Ddisertai dokumen limbah B3 (Manifest limbah B3).

- Menyerahkan Limbah B3 yang diangkut ke penerima yang sudah terlebih dahulu ditunjuk oleh pengirim (PerMen LH 18/2009 Pasal 4 ayat (2).

- Memiliki asuransi pencemaran lingkungan nilai minimal Rp. 5 milyar.

- Memiliki sistem tanggap darurat.

4. Pemanfaat

- Pemanfaat harus berbentuk badan usaha dan memiliki AMDAL

- Memiliki rekomendasi dari KLH dan izin dari departemen perindustrian.

- Meyimpan limbah B3 maksimla 90 hari sebelum dimanfaatkan.

- Memiliki sistem tanggap darurat.
- Memiliki laboratorium analisa LB3 dan tenaga terdidik di bidang pengelolaan LB3.

- Memiliki asuransi pencemaran lingkungan dengan nilai minimal Rp. 5 Milyar.

- Membuat dan menyimpan catatan tentang jenis, karakteristik, jumlah, dan waktu limbah B3 dikumpulkan, dimanfaatkan, dan produk yang dihasilkan, serta nama pengangkut yang melaksanakan pengiriman.

- Melaporkan pencatatan minimal 6 bulan sekali kepada KLH, atau berdasarkan surat izin pemanfaatan.

5. Pengolah

- Pengolah harus berbentuk badan usaha dan memiliki AMDAL.

- Memiliki izin dari KLH.

- Menyimpan limbah B3 maksimal 90 hari sebelum diolah atau limbah B3 yang dihasilkan.

- Memiliki sistem tanggap darurat.

- Memiliki laboratorium analisa LB3 dan tenaga terdidik di bidang pengelolaan LB3.

- Memiliki asuransi pencemaran lingkungan dengan nilai minimal Rp. 5 Milyar.

- Membuat dan menyimpan catatan tentang jenis, karakteristik, jumlah, dan waktu limbah B3 dikumpulkan, diolah, , serta nama pengangkut yang melaksanakan pengiriman.

- Melaporkan pencatatan minimal 6 bulan sekali kepada KLH, atau berdasarkan surat izin pengolahan.

6. Penimbun 
- Pengolah harus berbentuk badan usaha dan memiliki AMDAL.

- Memiliki izin dari KLH.

- Dapat dilakukan oleh penghasil dengan ketentuan yang berlaku sama dengan penimbun limbah B3.

- Memiliki sistem tanggap darurat.

- Memiliki laboratorium analisa B3 dan tenaga terdidik di bidang pengelolaan LB3.

- Memiliki asuransi pencemaran lingkungan dengan nilai minimal $\mathrm{Rp}$. 5 milyar.

- Membuat dan menyimpan catatan tentang sumber, jenis, karakteristik, dan jumlah limbah B3 yang ditimbun, serta nama pengangkut yang melakukan pengakutan.

- Melaporkan pencatatan minimal 6 bulan sekali kepada KLH, atau berdasarkan surat izin penimbunan.

Upaya yang pengelolaan lingkungan yang telah dilakukan oleh usaha pertambangan laut untuk mencegah timbulnya kerusakan terumbu karang, kekeruhan, serta limbah hidrokarbon.

\section{Hasil Pengukuran Kualitas Air Laut}

Air merupakan kebutuhan paling esensial bagi makhluk hidup. aktifitas manusia yang semakin meningkat dengan jumlah populasi yang cenderung naik dari waktu ke waktu berpotensi menimbulkan dampak terhadap penurunan kualitas lingkungan terurama kualitas air. Air laut merupakan komponen utama penyusunan keseluruhan air di muka bumi ini. Pengukuran kualitas air laut ditetapkan melaui pembandingan nilai hasil pengukuran dengan nilai baku mutu yang ditetapkan dalam keputusan Menteri Lingkungan Hidup Republik Indonesia Nomor 51 Tahun 2004 Lampiran III. Dengan adanya monitoring terhadap kualitas air laut diharapkan kegiatan penambangan yang dilakukan tidak mencemari perairan pantai dan laut. Parameter yang diukur meliputi kecerahan, kebauan, kekeruhan, residu tersuspensi, sampah, suhu (in-situ), dan lapisan minyak, salinitas, $\mathrm{pH}$, oksigen terlarut (Dissolved Oxygen), Biological Oxygen Demand ( $\left.\mathrm{BOD}_{2}\right)$, ammonia $\left(\mathrm{N}^{\left.-\mathrm{NH}_{3}\right)}\right.$, fosfat $\left(\mathrm{PO}_{4} \mathrm{P}\right)$, nitrat $\left(\mathrm{NO}_{3}-\mathrm{N}\right)$, Sianida $(\mathrm{CN})$, sulfide $\left(\mathrm{H}_{2} \mathrm{~S}\right)$. senyawa fenol total, surfaktan (detergen), minyak dan lemak, raksa (Hg), kromium VI (Cr VI), arsen (As), cadmium terlarut (Cd), tembaga terlarut $(\mathrm{Cu})$, timbal larut $(\mathrm{Pb})$, seng terlarut $(\mathrm{Zn})$, nikel $(\mathrm{Ni}), \quad \mathrm{PAH}$ (poliaromatik hidrokarbon), PCB total (Poliktor bifenil), Tributil Tin (TBT).

Berdasarkan penjelasan diatas, terlihat bahwa hasil analisis untuk keseluruhan tersebut jadi telah memenuhi baku mutu masing-masing parameter, kecuali pada parameter salinitas yang menunjukan hasil 35,7\% (titik 1), 34,8\% (titik 2), dan 37,5\% (titik 3) yang berarti melebihi baku mutu (33-34\%).

\section{KESIMPULAN}

Aktivitas pertambangan dilaut yang semakin marak di kabupaten Bangka saat ini telah berdampak terhadap menurunnya daya dukung dan daya tampung lingkungan, terjadinya penyusutan sumberdaya alam dan lingkungan, penerapan Standar Mutu Lingkungan Hidup yang masih lemah, masalah Pemanfaatan Dan Pengurasan Sumber 
Daya Alam (hutan, tanah, sumberdaya air, keanekaragaman hayati dan sumberdaya pesisir dan laut), dan pencemaran lingkungan. Kebijakan pertambangan yang diatur dalam UU No. 32 Tahun 2009 tentang Perlindungan dan Pengelolaan Lingkungan Hidup, terbit 3 Oktober 2009 pada pasal 1 yang menyebutkan bahwa izin lingkungan adalah izin yg diberikan kepada setiap orang yg melakukan usaha dan/atau kegiatan yang wajib AMDAL atau UKL-UPL dalam rangka perlindungan dan pengelolaan lingkungan hidup sebagar prasyarat untuk memperoleh izin usaha dan/atau kegiatan.

Hasil pengukuran kualitas air laut yang meliputi kecerahan, kebauan, kekeruhan, residu tersuspensi, sampah, suhu (in-situ), dan lapisan minyak, salinitas, $\mathrm{pH}$, oksigen terlarut (Dissolved Oxygen), Biological Oxygen Demand $\left(\mathrm{BOD}_{2}\right)$, ammonia $\left(\mathrm{N}-\mathrm{NH}_{3}\right)$, fosfat $\left(\mathrm{PO}_{4} \mathrm{P}\right)$, nitrat $\left(\mathrm{NO}_{3}-\mathrm{N}\right)$, Sianida $(\mathrm{CN})$, sulfide $\left(\mathrm{H}_{2} \mathrm{~S}\right)$. senyawa fenol total, surfaktan (detergen), minyak dan lemak, raksa $(\mathrm{Hg})$, kromium VI (Cr VI), arsen (As), cadmium terlarut (Cd), tembaga terlarut $(\mathrm{Cu})$, timbal larut $(\mathrm{Pb})$, seng terlarut $(\mathrm{Zn})$, nikel $(\mathrm{Ni}), \quad \mathrm{PAH}$ (poliaromatik hidrokarbon), PCB total (Poliktor bifenil), Tributil Tin (TBT) telah memenuhi baku mutu masing-masing parameter, kecuali pada pengukuran salinitas yang menunjukan hasil yang melebihi baku mutu tetapi masih dalam batas kewajaran.

Jadi setiap usaha atau kegiatan pertambangan di laut harus memiliki izin lingkungan supaya pertambangan di laut terarah sesuai dengan peraturan yang ada.
Kebijakan tersebut dan ketepatan sebuah program sudah mulai berjalan dengan cukup baik dan dengan ada kebijakan tersebut pemerintah kabupaten Bangka untuk mendorong penaatan perusahaan dalam pengelolaan lingkungan hidup melalui instrumen informasi.

\section{DAFTAR PUSTAKA}

Arif \& Zulkarnain. (2008). Dasar-Dasar Manajemen dalam Teknologi Informasi. Jurnal SAINTIKOM Vol. 5, No. 2 Agustus 2008.

Daryanto. (1997). Kamus Indonesia Lengkap. Surabaya : Apollo.

Sule, ET., Kurniawan. S. (2009). Pengantar Manajemen. Jakarta: Kencana Prenada Media Goup.

Fattah, N. (2011). Landasan Manajemen Pendidikan. Bandung : PT Remaja Rosdakarya.

Heriyansyah. (2015). Implementasi peraturan pemerintah nomor 78 tahun 2010 tentang reklamasi dan pascatambang (Studi Kasus Pada PT. Raja Kutai Baru Makmur di Desa Kutai Lama Kecamatan Anggana Kabupaten Kutai Kartanegara). eJournal Ilmu Pemerintahan, 3 (1) 2015: 520-534 ISSN 0000-0000, ejournal.ip.fisip-unmul.ac.id Copyright.

Heriyanto. (2009). Suatu Tinjauan Atas Penilaian Prestasi Kerja Pegawai Pada Pusat Penelitian Dan Pengembangan Sumber Daya Air.

Hosio. (2007). Kebijakan Publik dan Desentralisasi : Esai-Esai Dari Sorong. Yogyakarta: Laksbang Yogyakarta. 
Manik, J.D.N. (2014). Kebijakan Pertambangan Laut Timah Yang Berdampak Pada Lingkungan.

Manullang, M. (1983). Dasar-Dasar Manajemen. Edisi ketiga. Jakarta. Erlangga.

Moleong, J.L. (2004). Metode Penelitian Kualitatif. Bandung: Remaja Rosda Karya.

Nazir. M. (2003). Metode Penelitian. Jakarta: PT. Ghalia Indonesia.

Nugroho, R. (2004). Kebijakan Publik, Formulasi, Implementasi, dan Evaluasi. Jakarta : PT Gramedia.

Rusli, Budiman.2013. KEBIJAKAN PUBLIK: Membangun Pelayanan Publik Yang Responsif. Bandung : Hakim Publishing.

Subarsono, AG. (2011). Analisis kebijakan Publik : Konsep. Teori dan Aplikasi. Yogyakarta : Pustaka Pelajar.

Suharno. (2010). Dasar-Dasar Kebijakan Publik. UNY Press.

Sapanli, K. (2009). Analisis Kebijakan Pembangunan Ekonomi Kelautan Di Provinsi Kepulauan Bangka Belitung.

Soebandono. (2009). Sistem Manajemen Keselamatan dan Kesehatan Kerja (Pengertian dan Fungsi Manajemen).

Soemarwoto, O. (1994). Ekologi Lingkungan dan Pembangunan. Jakarta: Djambatan.

Soerjani. M. et al (editor). (1987). Lingkungan sumberdaya alam dan kependudukan dalam pembangunan. Jakarta : Penerbit Universitas Indonesia (UI-Press).

Soewartoyo dan Soetopo, T. (2009). Potensi sumber daya alam dan peningkatankualitas sumber daya manusia di kawasan Masyarakat Pesisir, kabupaten Bangka. Vol. IV, No. 2, 2009.
Vatria, B. (2013). Berbagai Kegiatan Manusia Yang Dapat Menyebabkan Terjadinya Degradasi Ekosistem Pantai Serta Dampak Yang Ditimbulkannya.

Wahyuni, Sasongko, P. Sasongko. (2013). Kandungan Logam Berat pada Air, Sedimen dan Plankton di Daerah Penambangan Masyarakat Desa Batu Belubang Kabupaten Bangka Tengah.

Widyastuti, M. (2007). Analisis ekonomi usaha timah tambang inkonvensional (ti) di kecamatan belinyu kabupaten bangka propinsi kepulauan bangka Belitung.

Winarno, B. (2013). Kebijakan Publik Teori, Proses, dan Studi Kasus. Yogyakarta CPAS (Center Of Academic Publishing Service).

Winarno, B. (2008). Kebijakan Publik Teori dan Proses. Jakarta: PT Buku Kita

Yustiani, Rusmaya, \& Pratama. (2012). Pengaruh Aktivitas Penambangan Timah Oleh Kapal Keruk Terhadap Kualitas Parameter Fisik (Kekeruhan, TSS, Suhu) Air Laut Di Teluk Kebalat Belinyu Kabupaten Bangka. Volume 14 Nomor 2 Desember 2012.

Mutiari, D. (2014). Manajemen Birokrasi dan Kebijakan (Penelusuran Konsep dan Teori). Yogyakarta: Pustaka Pelajar

\section{Undang-Undang dan peraturan lainnya:}

Undang-Undang No. 11 Tahun 1967 Tentang Pertambangan Umum.

Undang-Undang No 4 Tahun 2009 tentang Pertambangan Mineral dan Batubara.

Undang-Undang No. 32 tahun 2009 tentang Perlindungan dan Pengelolaan Lingkungan Hidup, terbit 3 Oktober 2009

PP No.78 Tahun 2010 Tentang Reklamasi dan Penutupan Tambang. 
